\title{
Modifikasi Mesin Peniris Minyak Sistem Spinner
}

\section{Modification of Spinner System}

\author{
Harmen, Imam Sofi'i, dan Ridwan Baharta \\ Jurusan Teknologi Pertanian, Politeknik Negeri Lampung \\ *e-mail : harmen@polinela.ac.id
}

\begin{abstract}
The process of draining oil is one of the processes that can affect the oil content of the frying or chips. The oil that is left in a lot of fried food or chips when stored for a long time will cause a rancid smell. Meanwhile, if consumed directly, it will affect the health of consumers because of high cholesterol levels. Most people do not know the consequences that occur if they consume excess oil. People who already know cannot do anything because the oil draining machines on the market are still quite expensive and their working capacity is limited. In the previous research, a draining machine with a tube system with a diameter of $40 \mathrm{~cm}$ and a height of $22.2 \mathrm{~cm}$ was made with an rpm of 517 . Within 5 minutes this system reduce oil content from $27 \%$ to $24,65 \%$. The data shown in strightline gaphic trend that mean the reduction oil conten is not optimal yet. For this reason, this research will be redesigned by extending the spinner axis and adding the bearings to 2 units, it is hoped that this addition will stabilize the spinner rotation, the rotation can be increased and the ability to reduce oil content increases. extending the drain axis and increasing the position of the bearing to 2, the draining machine has been able to function properly until 967 rpm rotation, from the test results for draining the cassava chip oil, within 5 minutes,

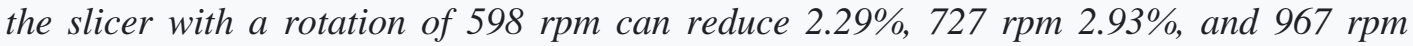
$4.27 \%$ rotation.
\end{abstract}

Keywords: modification, slicing machine, oil, chips

Naskah ini diterima pada tanggal 22 Oktober 2020, direvisi pada tanggal 5 Nopember 2020 dan disetujui untuk diterbitkan pada tanggal 15 Agustus 2020

\section{PENDAHULUAN}

Masyarakat sangat menggemari makanan yang mengandung minyak. Minyak mengandung Trigeliserida yang merupakan salah satu komponen kolesterol. Kolesterol yang tinggi dapat menyebabkan penyakit jantung koroner. Penyakit jantung koroner dapat dihindari atau dicegah dengan cara mengurangi kadar minyak pada makanan.

Cara meniriskan makanan pada skala rumah tangga, pedagang gorengan maupun UKM masih banyak yang dilakukan secara manual yaitu menaruh makanan yang sudah di goring diatas wajan. Cara penirisan seperti ini ternyata kurang efektif. Kadar minyak yang tinggi ini kalau disimpan lama menimbulkan bau tengik.

Pada penelitian sebelumnya telah dilakukan rancang bangun peniris minyak dengan metoda sentrifugal diameter $\phi 40 \mathrm{~cm}$ dengan tinggi $22,2 \mathrm{~cm}$ dan kecepatan putaran $517 \mathrm{rpm}$ 
(Harmen, 2018). Dalam waktu 5 menit mesin baru sanggup menurunkan kadar minyak 2,35\% dari $27 \%$ menjadi $24,65 \%$, tren gafik berbentuk garis lurus dengan $\mathrm{R}^{2} 0,9958$. Dari dimensi yang ada, mesin dapat ditingkatkan kemampuan penirisan minyaknya dengan meningkatkan putaran dan atau menambah diameternya.

Untuk meningkatkan kemampuan peniris dapat dilakukan dengan menambah kecepatan putaran mesin sesuai prinsip gaya sentrifugal. Masalah yang timbul adalah semakin tinggi putaran akan semakin meningkat juga getaran mesin. Untuk mengurangi atau mengghilangkan getaran ini perlu sumbu yang kokoh ketika diberikan putaran tinggi. Pada penelitian ini akan dilakukan perbaikkan rancangan dengan memperpanjang sumbu spinner sampai puncak tabung dan untuk mengokohkan kedudukan sumbu akan ditambah bantalan (bearing) menjadi 2, yang diletakkan di bawah tabung dan di bawah puli spinner, sehingga perbaikkan rancangan ini akan dapat meningkatkan putaran spinner.

Peniris yang dirancang sekarang memiliki sumbu sampai dasar tabung, sehingga untuk putaran tinggi menjadi tidak seimbang (tidak balance). Badan tabung bergetar sehingga tidak dapat mencapai putaran optimalnya. Semakin tinggi tabung maka akan semakin tidak stabil putaran peniris.

Dengan alasan alasan ini, maka pada penelitian ini akan dilakukan perbaikkan rancangan dengan memperpanjang sumbu spinner sampai puncak tabung. Untuk mengokohkan kedudukan sumbu akan ditambah bantalan menjadi 2, yang diletakkan di bawah tabung dan di bawah puli spinner. Perbaikkan rancangan ini diharapkan akan dapat meningkatkan putaran spinner.

Prinsip kerja mesin peniris minyak hampir sama dengan prinsip kerja mesin cuci ketika dalam proses pengeringan. Kedua mesin ini memanfaatkan gaya sentrifugal yang timbul akibat putaran. Mesin cuci menggunakan gaya sentrifugal yang timbul akibat putaran. Mesin cuci menggunakan gaya sentrifugal untuk membuat udara bergerak dan menguap, sedangkan peniris menggunakan gaya sentrifugal untuk menyaring minyak yang masih banyak terkandung dalam keripik (Istiqlaliyah H., 2002)

Gaya sentrifugal yang terjadi pada saat keranjang berputar, maka bahan atau produk yang ditiriskan akan bergerak menuju ke bagian sisi keranjang mesin peniris minyak atau spinner. Sehingga bahan atau produk yang ukurannya lebih kecil dari ukuran lubang keranjang seperti minyak atau air akan bergerak keluar melewati keranjang tabung mesin peniris minyak atau spinner. Gaya sentripetal dipengaruhi oleh jari jari keranjang, semakin besar jari-jari keranjang semakin besar gaya sentripetal yang dihasilkan. Sesuai dengan rumus berikut: berdasarkan HK II Newton: 


$$
F s=m a_{s}=m \frac{v^{2}}{R}=m \omega^{2} R
$$

Dimana

Fs = gaya sentripetal $(\mathrm{N})$

$\mathrm{m}=$ massa benda $(\mathrm{kg})$

$\mathrm{a}_{\mathrm{s}}=$ percepatan sentripetal $\left(\mathrm{m} / \mathrm{s}^{2}\right)$

$\mathrm{v}=$ kecepatan linear benda $(\mathrm{m} / \mathrm{s})$

$\square=$ kecepatan sudut $(\mathrm{rad} / \mathrm{s})$

$\mathrm{R}=$ jari-jari lintasan $(\mathrm{m})$

Penelitian mengenai mesin peniris minyak sudah banyak dilakukan, mulai dari peniris semi mekanis sampai dengan yang menggunakan silinder peniris bahkan yang menggunakan tekanan vakum. Nur, R. (2010) Rancang Bangun Mesin Peniris Bawang Goreng untuk Meningkatkan Produksi Bawang Goreng pada Industri Rumah Tangga, Romadloni, Burhanudin Syahri. 2012. Perancangan Mesin Peniris Minyak Pada Kacang Telur. Satrio, D. (2013) Merancang bangun mesin peniris Abon sapi. Istiqlaliyah H. (2013) Perencanaan Mesin Peniris Minyak Pada Keripik Nangka dengan Kapasitas 2,5 kg/menit. Umardani M.R. (2013) Alat Peniris minyak pada makanan setelah digoreng skala rumah tangga, Umam K. (2014) Mesin Peniris jamur goreng dengan kontrol timer. Pada penelitian sebelumnya telah dilakukan rancang bangun peniris minyak dengan metoda tabung berputar dengan diameter $\phi 40 \mathrm{~cm}$ dengan tinggi $22 \mathrm{~cm}$ dan kecepatan putaran 517 rpm (Harmen, 2018)

Tujuan penelitian ini adalah: Meningkatkan kemampuan mesin peniris minyak dengan cara menambah panjang sumbu spinner sampai diujung tabung sehingga putarannya menjadi stabil dengan demikian akan dapat meningkatkan putarannya. Melakukan uji unjuk kerja mesin di laboratorium.

\section{METODE PENELITIAN}

Penelitian ini dilaksanakan di Laboratorium Logam dan Otomotif Mekanisasi Pertanian Politeknik Negeri Lampung dari bulan Mei 2020 sampai dengan bulan Oktober 2020.

Alat yang digunakan pada penelitian ini adalah: mesin rol plat, mesin las, bor listrik, gerinda kunci kunci, tacho meter, timbangan. Bahan penelitian: plat stainless steel, besi poros, besi siku, plat besi pulley, v-belt, motor listrik, cat kuas, kabel, keripik singkong sudah digoreng dan telah diperiksa kadar minyaknya.

Perancangan dimulai dari memodifikasi tabung peniris Gambar 1 dan Gambar 2, dimana tabung belum memiliki sumbu sampai kepuncaknya dan bearingnya hanya 1. Maka untuk itu dibuatlah rancangan baru seperti Gambar 3. 


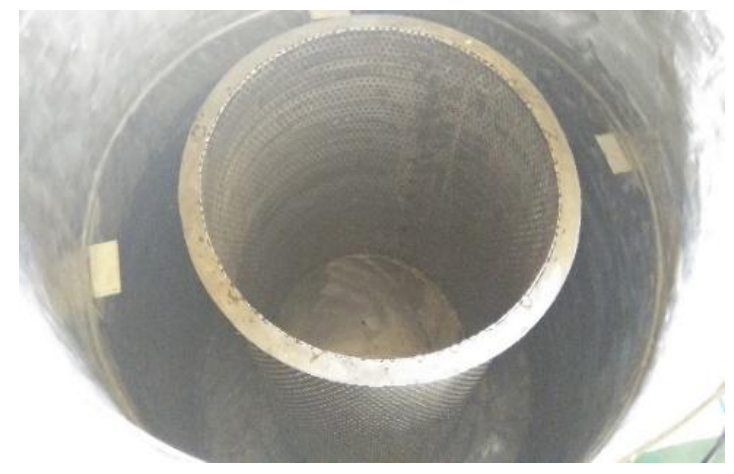

Gambar 1. Rancangan

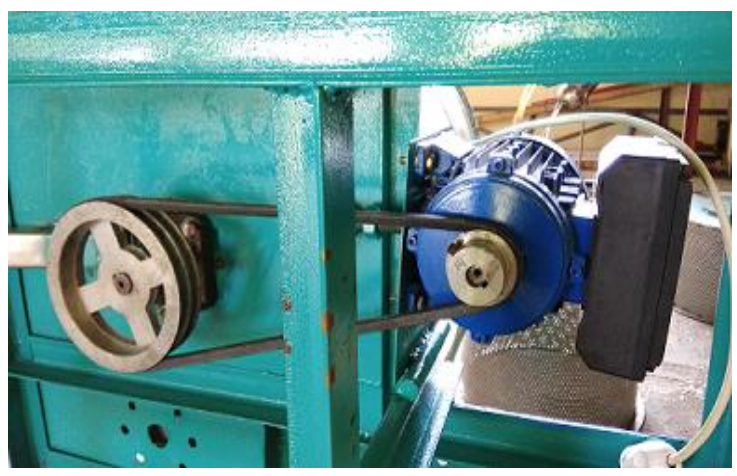

Gambar 2. Sumbu dengan 1 Puli pemindah daya

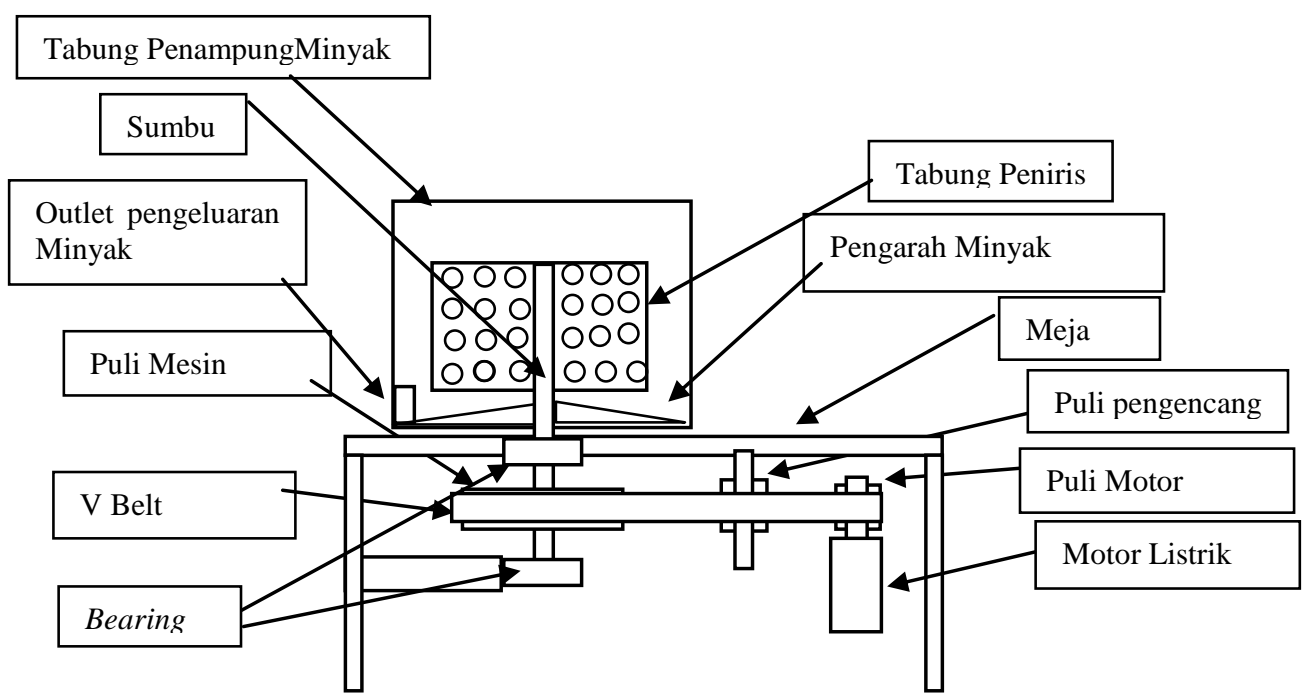

Gambar 3. Struktur Mesin Peniris Minyak

Secara fungsional mesin peniris minyak ini terdiri dari bagian utama, yaitu tabung peniris minyak (bagian yg akan ditingkatkan kemampuan penirisan minyaknya), tabung penampung minyak, outlet pengeluaran minyak, sumbu, puli mesin, V Belt, bearing, tabung peniris, pengarah minyak, meja, puli pengencang, puli motor dan motor listrik.

Secara struktural rancangan mesin peniris dapat dilihat pada (Gambar 3) tabung penampung minyak, dibuat dari seng plat, ukuran disesuaikan dengan ukuran tabung peniris. Outlet pengeluaran minyak, dibuat dari seng plat sama seperti tabung penampung. Sumbu, dibuat dari as baja. Puli mesin, dibuat dari baja tuang atau aluminium tuang. $V$ belt, dibuat dari karet berlapis benang dibeli dipasaran. Bearing, ukuran disesuaikan dengan kebutuhan dibeli dipasaran. Tabung peniris, tabung peniris (Gambar 1) dibuat dari baja anti karat (stainless steel) diameter $(\phi) 40 \mathrm{~mm}$, tinggi $22,2 \mathrm{~cm}$ (volume $27.6 \mathrm{~cm}^{3}$ ), merupakan bahagian yang akan ditingkatkan kemampuan dengan metoda peningkatan kecepatan putarannya sampai $1000 \mathrm{rpm}$. Pengarah minyak, dibuat dari seng plat sama dengan tabung penampung minyak. Meja/rangka, sudah ada. Puli pengencang, puli motor, motor $3 / 4$ HP sudah ada. 
Pengujian fungsional alat dilakukan terhadap tabung peniris, tabung pengumpul, saluran pengeluaran, motor listrik, sistem transmisi, rangka dan sistem kelistrikan. Kegiatan ini bertujuan untuk memastikan apakah bagian-bagian berfungsi dengan baik.

Pengujian unjuk kerja alat dilakukan untuk mengetahui kemampuan alat mengeluarkan minyak selama 5 menit, dengan melakukan pengamatan setiap 1 menit. Pengurangan berat keripik akan dicatat dan dikonversi sebagai penurunan berat minyak. Penurunan berat minyak akan dikonversi sebagai persentase penurunan kadar minyak. Penurunan kadar minyak akan dibuat dalam bentuk gafik. Pengujian dilakukan dengan 3 kali ulangan dengan waktu penirisan 1-5 menit.

\section{HASIL DAN PEMBAHASAN}

Telah dilakukan modifikasi rancangan sumbu peniris, bearing peniris dari hasil Gambar 3. Hasil rancangan dapat dilihat pada Gambar 4a, 4b dan 4c. Mesin peniris minyak hasil rancang bangun terdiri dari bahagian, yaitu: tabung peniris, tabung penampung, sumbu, outlet pengeluaran, puli mesin, V Belt, bearing, motor listrik, puli motor, puli pengencang meja, tabung peniris.

Mesin ini dirancang memiliki spesifikasi: panjang $880 \mathrm{~mm}$, lebar $820 \mathrm{~mm}$ dan tinggi 115 $\mathrm{mm}$. Dengan spesifikasi yang ringkas ini diharapkan mesin dapat disimpan pada ruang yang kecil, mudah dibawa-bawa dan mudah dibongkar pasang. Mesin peniris ini menggunakan motor listrik 0,75 HP dengan putaran motor antara 1400-1500 rpm. Perbandingan putaran puli yang digunakan adalah $2: 5,2: 4$ dan $2: 3$ Sehingga dalam pengoperasiannya motor listrik sistem transmisi dapat mereduksi putaran motor antara 500 sampai $1000 \mathrm{rpm}$. Penampilan dari mesin peniris hasil modifikasi dapat dilihat pada Gambar 4a, 4b dan 4c.

Dari data pengukuran dengan perbandingan puli $2: 5$, didapatkan putaran spinner 598 rpm, perbandingan puli 2: 4 didapatkan putaran spinner $727 \mathrm{rpm}$ dan perbandingan puli $2: 3$ didapatkan putaran spiner $967 \mathrm{rpm}$. Putaran spinner yg didapat inilah yg dijadikan untuk pengujian kemampuan spinner dalam mengeluarkan minyak dari keripik

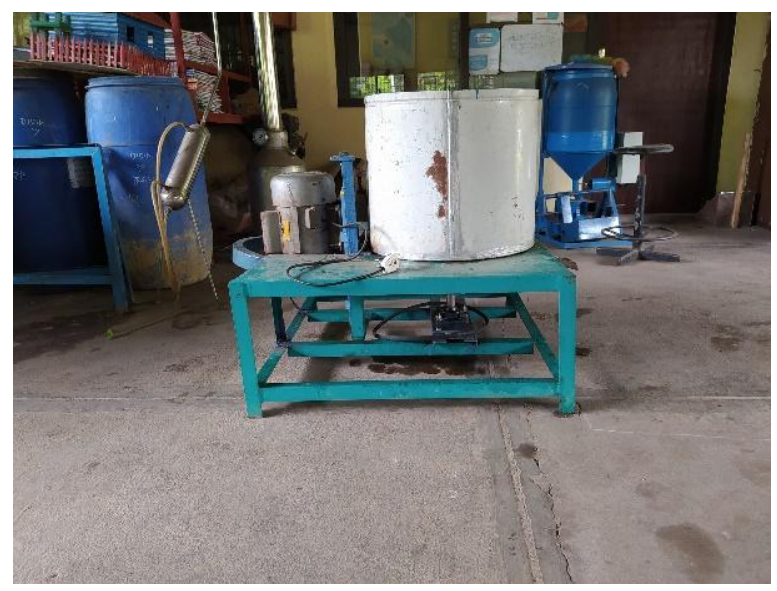

Gambar 4a. Hasil rancangan keseluruhan 


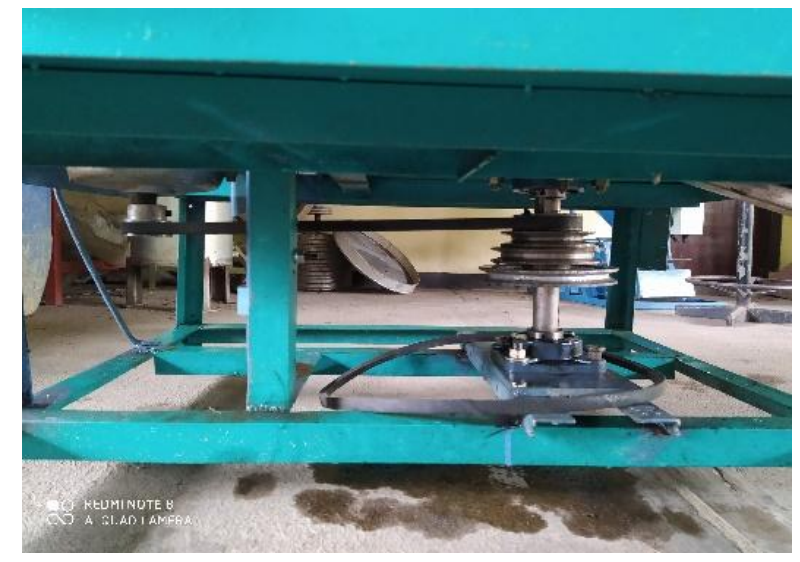

Gambar 4b. Hasil rancangan kedudukan modifikasi bearing

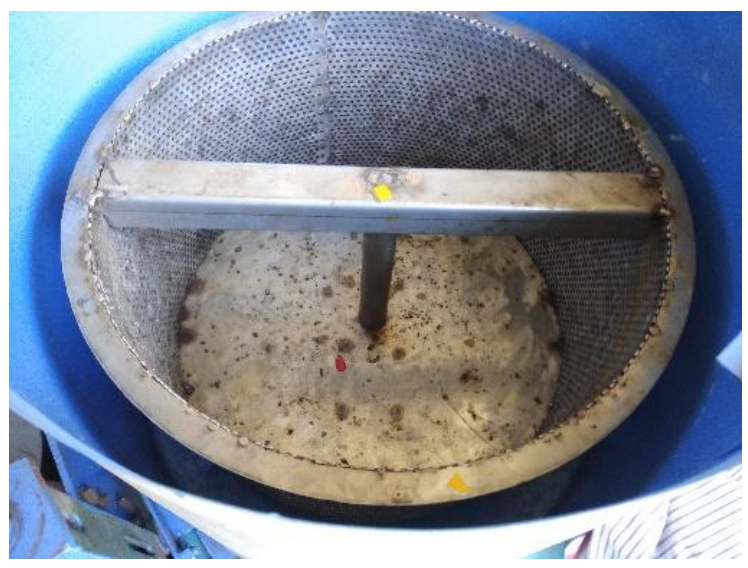

Gambar 4c. Hasil rancangan perpanjangan sumbu spinner

Mesin peniris yang dibuat diuji menggunakan keripik yang dipesan dari pengajin keripik di pesawaran. Sebelum diuji kemampuannya, keripik singkong diperiksa dulu kadar minyaknya. Dari pemeriksaan laboratorium kadar minyak didalam keripik adalah 27,15\%. Dari $1500 \mathrm{~g}$ keripik, kandungan minyaknya adalah 407,25 g. Inilah dasar untuk menentukan kemampuan peniris mengeluarkan minyak dari keripik. Hasil pengujian Penurunan kadar minyak keripik seperti tabel 1.

Tabel 1. Penurunan berat minyak berdasarkan lama ditiriskan pada putaran $598 \mathrm{rpm}(\mathrm{g})$

\begin{tabular}{ccccccc}
\hline \multirow{2}{*}{ Ulangan } & \multicolumn{6}{c}{ Berat minyak bahan pada putaran 598 rpm } \\
\cline { 2 - 7 } & 0 & 1 & 2 & 3 & 4 & 5 \\
\cline { 2 - 7 } & 407,25 & 391,25 & 382,25 & 378,25 & 374,25 & 372,25 \\
\hline 1 & 407,25 & 393,25 & 388,25 & 385,25 & 383,25 & 379,25 \\
\hline 2 & 407,25 & 381,25 & 376,25 & 373,25 & 369,25 & 367,25 \\
\hline 3 & 407,25 & 388,58 & 382,25 & 378,92 & 375,58 & 372,92 \\
\hline Rata-rata
\end{tabular}

Dari Tabel 1, setelah ditiriskan memperlihatkan pada 0 menit berat keripk rata-rata 407,25 $\mathrm{g}$, menit 1 terendah $381,25 \mathrm{~g}$, tertinggi $393,25 \mathrm{~g}$, rata rata rata $388,58 \mathrm{~g}$, menit ke-2 terendah $376,25 \mathrm{~g}$ tertinggi $388,25 \mathrm{~g}$, rata rata $382,25 \mathrm{~g}$. Menit ke-3 terendah $373,25 \mathrm{~g}$, tertinggi $385,25 \mathrm{~g}$, rata rata 378,92 g. Menit ke-4 terendah 369,25 g, tertinggi 383,25 g, rata rata 375,58 g. Menit ke-5 terendah $367,25 \mathrm{~g}$, tertinggi $379,25 \mathrm{~g}$, rata rata $372,92 \mathrm{~g}$.

Untuk melihat penurunan kadar minyak dapat dilihat pada Tabel 2 dan Gambar 5. 
Tabel 2. Hasil uji kemampuan penirisan minyak pada putaran $598 \mathrm{rpm}(\%)$

\begin{tabular}{ccccccc}
\hline \multirow{2}{*}{ Ulangan } & \multicolumn{7}{c}{ Penurunan kadar minyak pada putaran 598 rpm (\%) } \\
\cline { 2 - 7 } & 0 & 1 & 2 & 3 & 4 & 5 \\
\cline { 2 - 7 } & 0 & 1,07 & 1,67 & 1,93 & 2,20 & 2,33 \\
\hline 1 & 0 & 0,93 & 1,27 & 1,47 & 1,60 & 1,87 \\
\hline 2 & 0 & 1,73 & 2,07 & 2,27 & 2,53 & 2,67 \\
\hline 3 & 0 & 1,24 & 1,67 & 1,89 & 2,11 & 2,29 \\
\hline Rata-rata & 0
\end{tabular}

Dari Tabel 2, setelah ditiriskan memperlihatkan pada 0 menit penurunan kadar minyak keripik rata-rata $0 \%$. Menit 1 penurunan kadar minyak keripik terendah $0,93 \%$, tertinggi $1,73 \%$ tertinggi rata-rata $1,24 \%$, menit ke-2 penurunan kadar minyak keripik terendah 1,27\% tertinggi $2,07 \%$, rata rata $1,67 \%$. Menit ke-3 terendah $1,47 \%$ tertinggi $2,27 \%$, rata rata $1,89 \%$. Menit ke-4 terendah $1,60 \%$ tertinggi $2,53 \%$, rata rata 2,11\%. Menit ke 5 terendah $1,87 \%$ tertinggi $2,67 \%$, rata rata 2,29\%. Untuk melihat tren gafiknya dapat dilihat pada Gambar 5. Tren gafik memperlihatkan garis logaritmik, artinya dari menit ke menit kemampuan penirisan cenderung menurun.

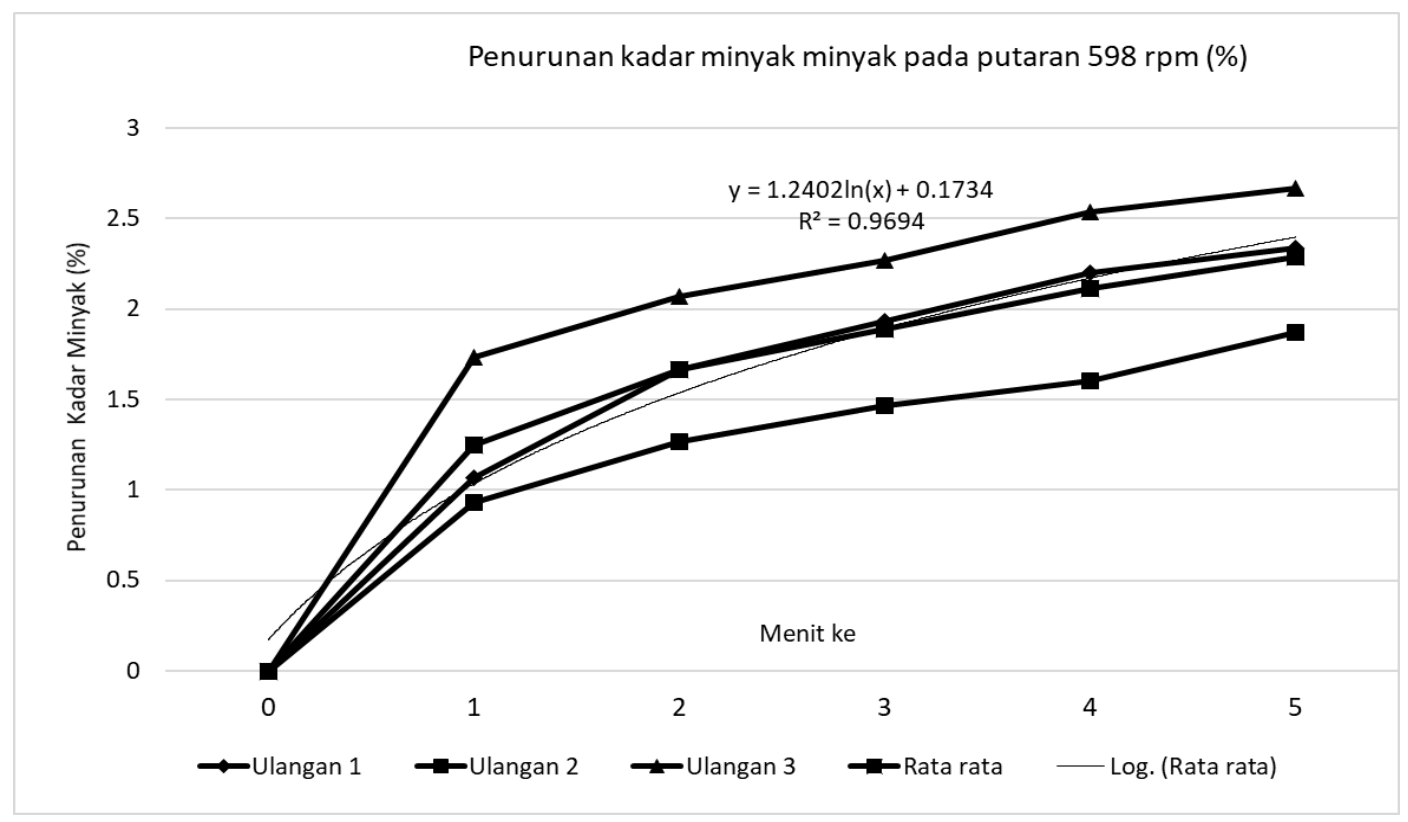

Gambar 5. Penurunan kadar Minyak berdasarkan lama ditiriskan pada pada putaran $598 \mathrm{rpm}$

Tabel 3. Penurunan Berat keripik berdasarkan lama ditiriskan pada putaran 727 rpm

\begin{tabular}{ccccccc}
\hline \multirow{2}{*}{ Ulangan } & \multicolumn{6}{c}{ Penurunan Kandungan minyak pada putaran $727 \mathrm{rpm}(\mathrm{g})$} \\
\cline { 2 - 7 } & 0 & 1 & 2 & 3 & 4 & 5 \\
\hline 1 & 407,25 & 388,25 & 382,25 & 375,25 & 371,25 & 366,25 \\
\hline 2 & 407,25 & 388,25 & 380,25 & 373,25 & 367,25 & 364,25 \\
\hline 3 & 407,25 & 380,25 & 372,25 & 367,25 & 361,25 & 359,25 \\
\hline Rata-rata & 407,25 & 385,58 & 378,25 & 371,92 & 366,58 & 363.25 \\
\hline
\end{tabular}


Dari Tabel 3, setelah ditiriskan memperlihatkan pada 0 menit berat keripk rata-rata 407,25 $\mathrm{g}$, menit 1 berat keripik terendah $380,25 \mathrm{~g}$, tertinggi $388,25 \mathrm{~g}$ rata rata $385,58 \mathrm{~g}$, menit ke-2 terendah $372,25 \mathrm{~g}$ tertinggi $382,25 \mathrm{~g}$, rata rata $378,25 \mathrm{~g}$. Menit ke-3 terendah 367,25 g, tertinggi 375,25 , rata rata $371,92 \mathrm{~g}$. Menit ke-4 terendah 361,25, tertinggi 371,25, rata rata 366,58 g. Menit ke 5 terendah $359,25 \mathrm{~g}$ tertinggi $366,25 \mathrm{~g}$, rata rata 363,25 g. Untuk melihat penurunan kadar minyak dapat dilihat pada Tabel 4 dan Gambar 6.

Tabel 4. Hasil uji kemampuan penirisan minyak pada putaran $727 \mathrm{rpm}(\%)$

\begin{tabular}{ccccccc}
\hline \multirow{2}{*}{ Ulangan } & \multicolumn{7}{c}{ Penurunan kadar minyak pada putaran 727 rpm (\%) } \\
\cline { 2 - 7 } & 0 & 1 & 2 & 3 & 4 & 5 \\
\cline { 2 - 7 } & 0,00 & 1,27 & 1,67 & 2,13 & 2,40 & 2,73 \\
\hline 1 & 0,00 & 1,27 & 1,80 & 2,27 & 2,67 & 2,87 \\
\hline 2 & 0,00 & 1,80 & 2,33 & 2,67 & 3,07 & 3,20 \\
\hline Rata-rata & 0,00 & 1,44 & 1,93 & 2,36 & 2,71 & 2,93 \\
\hline
\end{tabular}

Dari Tabel 4, setelah ditiriskan memperlihatkan pada 0 menit penurunan kadar minyak keripik rata-rata $0 \%$. Menit 1 penurunan kadar minyak keripik terndah 1,27, teritinggi 1,80 masih rata-rata $1,44 \%$, menit ke-2 penurunan kadar minyak keripik terendah $1,67 \%$ tertinggi $2,33 \%$, rata rata $1,93 \%$. Menit ke-3 terendah 2,13\% tertinggi $2,67 \%$, rata rata 2,36\%. Menit ke-4 terendah $2,40 \%$ tertinggi $3,07 \%$, rata rata $2,71 \%$. Menit ke-5 terendah $2,73 \%$ tertinggi $3,20 \%$, rata rata 2,93\%. Untuk melihat tren gafiknya dapat dilihat pada Gambar 6. Tren gafik memperlihatkan logaritmik, artinya pada awal penirisan minyak yang keluar kadarnya lebih banyak, menit berikutnya semakin menurun.

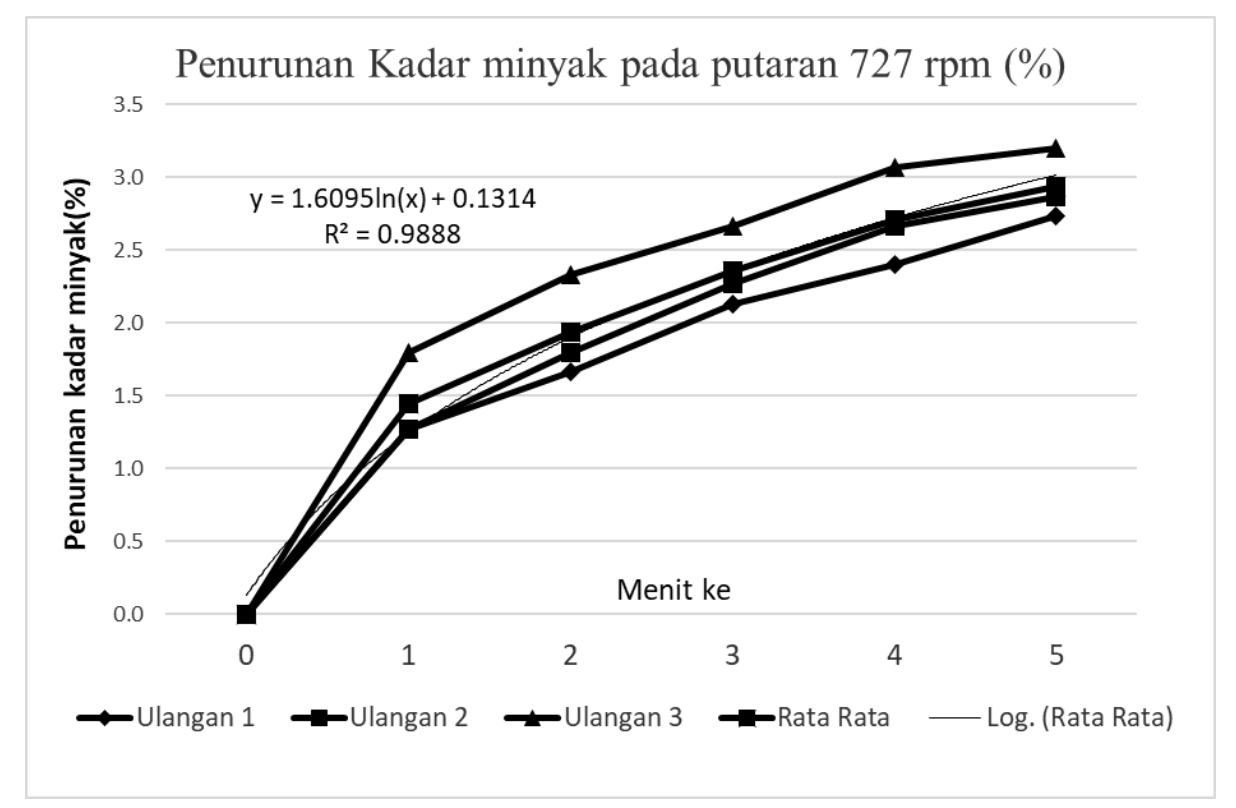

Gambar 6. Penurunan kadar Minyak berdasarkan lama ditiriskan pada pada putaran $727 \mathrm{rpm}$.

154 Volume 12, Nomor 3| Desember 2020: 127-181 
Tabel 5. Penurunan berat minyak berdasarkan lama pada putaran $967 \mathrm{rpm}$

\begin{tabular}{crrrrrr}
\hline & \multicolumn{6}{c}{ Berat minyak setelah ditirikan dengan putaran 967 rpm } \\
\cline { 2 - 7 } Ulangan & \multicolumn{7}{c}{ Menit ke $(\mathrm{g})$} \\
\cline { 2 - 7 } & 0 & 1 & 2 & 3 & 4 & 5 \\
\hline 1 & 407,25 & 377,25 & 364,25 & 355,25 & 347,25 & 344,25 \\
\hline 2 & 407,25 & 381,25 & 370,25 & 364,25 & 353,25 & 348,25 \\
\hline 3 & 407,25 & 374,25 & 358,25 & 347,25 & 341,25 & 337,25 \\
\hline Rata-rata & 407,25 & 377,5833 & 364,25 & 355,5833 & 347,25 & 343,25 \\
\hline
\end{tabular}

Dari Tabel 5, setelah ditiriskan memperlihatkan pada 0 menit berat keripik rata-rata 407,25 $\mathrm{g}$, menit 1 berat keripik terendah $374,25 \mathrm{~g}$ tertinggi $381,25 \mathrm{~g}$, rata rata rata $377,58 \mathrm{~g}$, menit ke-2 berat terendah $358,25 \mathrm{~g}$, tertinggi $370,25 \mathrm{~g}$ rata rata $364,25 \mathrm{~g}$. Menit ke-3 terendah $347,25 \mathrm{~g}$ tertinggi $364,25 \mathrm{~g}$, rata rata $355,58 \mathrm{~g}$. Menit ke-4 terendah $341,25 \mathrm{~g}$, tertinggi $353,25 \mathrm{~g}$, rata rata 347,25 g. Menit ke-5 terendah 337,25 g, tertinggi 348,25 g, rata rata 343,25 g. Untuk melihat penurunan kadar minyak dapat dilihat pada Tabel 6 dan Gambar 7.

Tabel 6. Hasil uji kemampuan penirisan minyak peniris pada $967 \mathrm{rpm}(\%)$

\begin{tabular}{ccccccc}
\hline \multirow{2}{*}{ Ulangan } & \multicolumn{7}{c}{ Penurunan kadar minyak pada putaran 967 rpm (\%) } \\
\cline { 2 - 7 } & 0 & 1 & 2 & 3 & 4 & 5 \\
\cline { 2 - 7 } & 0,00 & 2,00 & 2,87 & 3,47 & 4,00 & 4,20 \\
\hline 1 & 0,00 & 1,73 & 2,47 & 2,87 & 3,60 & 3,93 \\
\hline 2 & 0,00 & 2,20 & 3,27 & 4,00 & 4,40 & 4,67 \\
\hline 3 & 0,00 & 1,98 & 2,87 & 3,44 & 4,00 & 4,27 \\
\hline Rata rata & 0
\end{tabular}

Dari Tabel 6, setelah ditiriskan memperlihatkan pada 0 menit penurunan kadar minyak keripik rata-rata $0 \%$. Menit 1 penurunan kadar minyak keripik terendah 1,73\%, tertinggi 2,20\%, rata rata $1,98 \%$. Menit ke-2 terendah 2,47\%, tertinggi 3,27\%, rata rata 2,87\%. Menit ke-3 terendah $2,87 \%$ tertinggi $4,00 \%$, rata rata $3,44 \%$. Menit ke-4 terendah 3,60\% tertinggi $4,40 \%$, rata rata 4,00\%. Menit ke-5 terendah 3,93\% tertinggi 4,67\%, rata rata 4,27\%. Tren gafik memperlihatkan garis logaritmik, artinya semakin lama waktu penirisan, kemampuan peniris untuk mengeluarkan minyak semakin menurun Gambar. 7.

Tabel 7. Rata-rata penurunan kadar minyak berdasarkan putaran mesin (\%)

\begin{tabular}{ccccccc}
\hline \multicolumn{7}{c}{ Rata rata penurunan kadar minyak } \\
\hline \multirow{2}{*}{ Putaran (rpm) } & \multicolumn{7}{c}{ Menit ke (\%) } \\
\cline { 2 - 7 } & 0 & 1 & 2 & 3 & 4 & 5 \\
\hline 598 & 0 & 1,24 & 1,67 & 1,89 & 2,11 & 2,29 \\
\hline 727 & 0 & 1,44 & 1,93 & 2,36 & 2,71 & 2,93 \\
\hline 967 & 0 & 1,98 & 2,87 & 3,44 & 4,00 & 4,27 \\
\hline
\end{tabular}




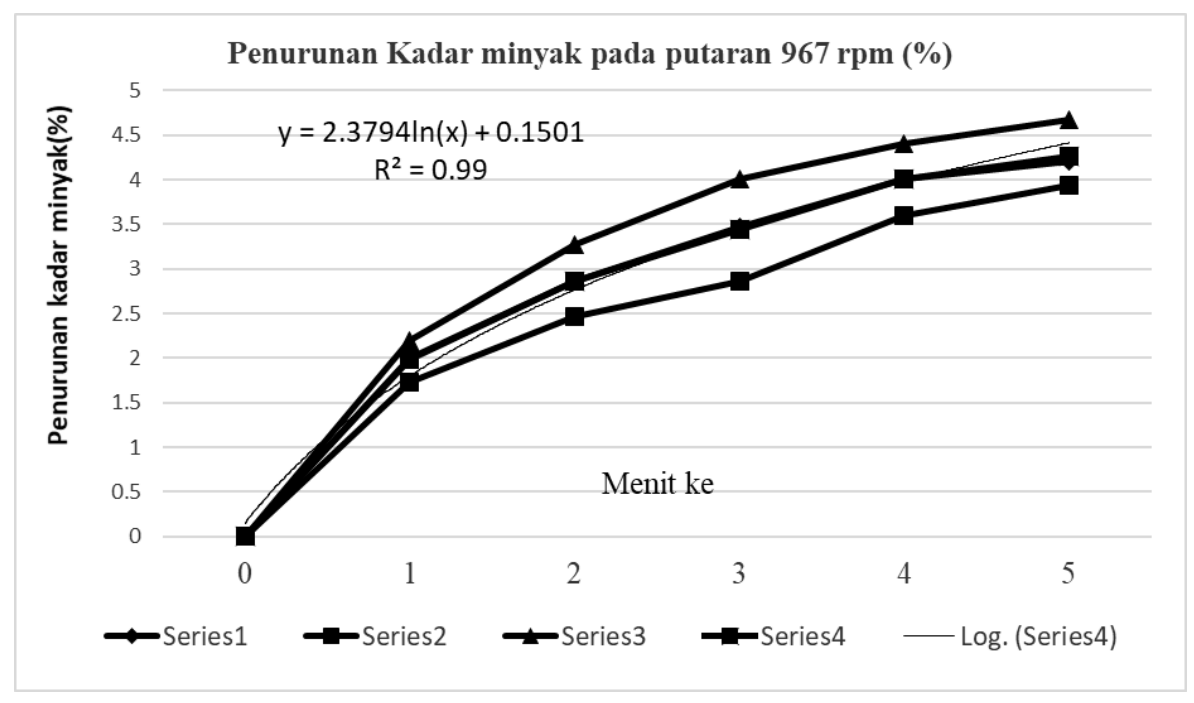

Gambar 7. Penurunan kadar Minyak berdasarkan lama ditiriskan pada pada putaran $967 \mathrm{rpm}$

Dari Tabel 7, Gambar 5, 6, 7, dan Gambar 8 memperlihatkan bahwa peniris dengan putaran 598 rpm gafiknya adalah $\mathrm{y}=1,2402 \ln (\mathrm{x})+0,1734$ dengan $\mathrm{R} 2=0,9694$. Peniris dengan putaran $727 \mathrm{rpm}$ gafiknya adalah $\mathrm{y}=1,6095 \ln (\mathrm{x})+0,1314$ dengan $\mathrm{R} 2=0,9888$. Peniris dengan putaran 967 rpm gafiknya adalah $\mathrm{y}=2,3794 \ln (\mathrm{x})+0,1501$ dengan $\mathrm{R} 2=0,9931$. Dari tren kemiringan gafik memperlihatkan bahwa peniris dengan putaran $967 \mathrm{rpm}$ cenderung mengeluarkan minyak lebih banyak dari pada peniris yang dengan putaran $598 \mathrm{rpm}$ dan $727 \mathrm{rpm}$.

Penurunan kadar minyak dipengaruhi oleh gaya sentrifugal yang diterima minyak yang akan dikeluarkan dari keripik. Gaya sentrifugal dipengaruhi oleh kecepatan putaran dan diameter peniris. Semakin cepat putaran dan semakin besar diameter peniris semakin besar gaya sentrifugal yang diterima minyak sehingga minyak cepat keluar dari kelipik. Pada penelitian ini penurunan kadar minyak dipengaruhi oleh putaran peniris

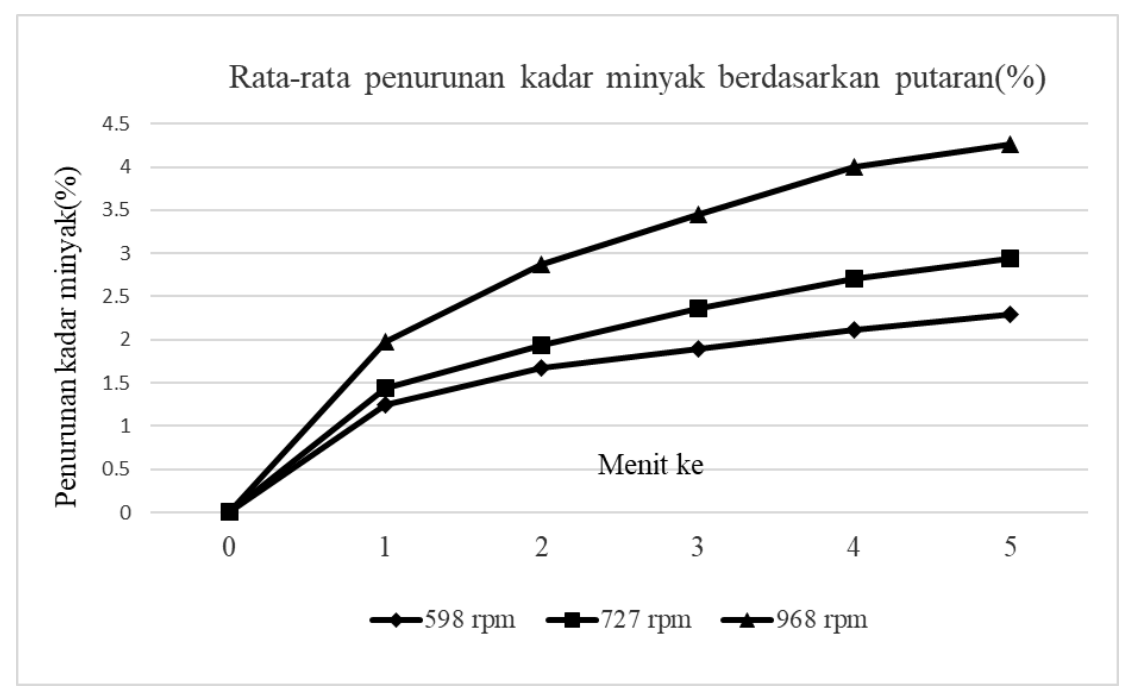

Gambar 8. Rata-rata penurunan kadar minyak berdasarkan putaran peniris (\%)

156 Volume 12, Nomor 3| Desember 2020: 127-181 


\section{KESIMPULAN}

Telah buat tabung peniris dengan memperpanjang sumbu peniris dan penambahan kedudukan bearing menjadi 2 unit. Mesin peniris telah dapat berfungsi dengan baik sampai putaran $967 \mathrm{rpm}$. Dari hasil pengujian untuk peniriskan minyak keripik singkong, dalam waktu 5 menit, peniris dengan putaran $598 \mathrm{rpm}$ dapat menurunkan sampai 2,29\%, putaran $727 \mathrm{rpm}$ sampai 2,93\%, dan putaran $967 \mathrm{rpm}$ sampai $4,27 \%$.

\section{DAFTAR PUSTAKA}

Harmen, 2018. Modifikasi Mesin Peniris Minyak Sistim Tabung. Prosiding Seminar Nasional Pengembangan Teknologi Pertanian Politeknik Negeri Lampung 08 Oktober 2018 ISBN 978602-5730-68-9 halaman347-356

Istiqlaliyah H. 2013. Perencanaan MesinPeniris Minyak Pada Keripik Nangka Dengan Kapasitas 2,5Kg/Menit.TeknikMesin S1, Fakultas Teknik, Univ. Nusantara PGI Kediri. Skripsi.

Nur R., 2010. Rancang Bangun Mesin Peniris Bawang Goreng untuk Meningkatkan Produksi Bawang Goreng pada Industri Rumah Tangga. Jurnal Teknik Mesin Politeknik Negeri Ujung pandang.

Satrio, D. 2013. Merancang bangun mesin peniris Abon sapi. Laporan Tugas Akhir. UNS Solo.

Umam K.(2014) Mesin Peniris Jamur Goreng Dengan Kontrol Timer, Tugas Akhir. Progam Diploma Vokasi. Universitas Yogyakarta.

Umardani, M.R. 2013. Alat Peniris minyak Pada Makanan Setelah Digoreng Skala Rumah Tangga. Tugas Akhir. Sekolah Vokasi Universitas Gajah Mada. Yogyakarta. 